\title{
ACCEPTANCE OF HIBAH AS AN ALTERNATIVE MECHANISM IN MUSLIMS ASSET MANAGEMENT
}

\author{
Khairiah Ahmad ${ }^{1}$, Rozaiha Ab Majid, Zaharah Abdullah, Siti Fatimah Noor Minhad, Shafinar \\ Ismail $^{2}$ \\ ${ }^{I}$ Faculty of Accountancy, Universiti Teknologi MARA, Melaka \\ ${ }^{2}$ Faculty of Business Management, Universiti Teknologi MARA, Melaka
}

\begin{abstract}
This study is aimed to identify the acceptance of hibah by beneficiaries based on cases registered in Melaka. Using secondary data collected from the Melaka Syariah Court and Amanah Raya Berhad Melaka, a number of hibah cases were identified from 2013-2015 and highlighted for further discussion in the paper. Interviews, telephone and email correspondences were conducted to further understand the issues concerning hibah cases and their reasoning. The findings indicated that the highest number of registered on hibah cases was recorded in 2015, increasing from 2013. The data result shows that there are more than 20 cases recorded in Melaka except only 12 cases in 2013. Due to increasing number of cases regarding hibah, it shows that citizen of Melaka is still low in understanding the concept and implementation of hibah. Therefore, it is a need to have a standard guideline regarding hibah to avoid any dispute about this matter in the future. Besides that, the dissemination of knowledge about hibah should be done in order to increase the awareness about the acceptable procedure of hibah because it is considered as the best alternative of asset management and to avoid unclaimed Muslim asset.
\end{abstract}

Keywords: Hibah, dissatisfaction, beneficiaries, court cases

\section{INTRODUCTION}

\subsection{Background}

Over the last five years, Malaysia has been experiencing an increase in the number of court cases over the dispute in regards to legal beneficiaries and heirs over the transfer of their inheritance to another person through the implementation of hibah. The cases are brought to Syariah Court and are heard under The Administration of Islamic Law (Federal Territories) Act 1993 (Act 505) Part IV Sec. 46 (1) (2) (b) (vi) - Syariah High Court's Jurisdiction.

In Melaka alone, the Melaka Tengah district recorded a progressive increase on hibah cases from 2010 to 2012. As reported in Mohd Yusof and Ahmad (2013), there were only 10 cases in year 2010 and significantly increased in 2011 and 2012 to 24 and 32 cases respectively. The increasing number of court cases showed that the implementation of hibah has resulted in growing dissatisfactions among related parties especially among family members who are also the beneficiaries. Eventually, these feelings of dissatisfaction may lead to a more complex dispute among related parties. 
Therefore, it is essential to understand the reasons to this issue. The dissatisfaction may be due to the lack of knowledge and poor awareness on hibah among parties involved. Hibah may have not been done according to a specific procedure. For that, this research is conducted to understand the acceptance of hibah among the legal beneficiaries. Additionally, the significant of this study also lies on the fact that most of the previous research had only focused on issues relating to zakat, baitulmal and wakaf instead of hibah.

\subsection{Hibah as an alternative mechanism for asset management}

According to the Islamic term, hibah refers to a contract that entails granting ownership of the property to someone else during his/her lifetime without any reprisal (Muda, 2008) outlined five requirements of hibah which include: i). an akad (contract) of granting property ownership to a specific party; ii). the property that can be given as hibah is a physical property and not debt; iii). hibah contract is made without imposing any reprisal; iv). hibah contract is in effect during the lifetime of the hibah provider; v). hibah is made voluntarily and the contract is made with no intention to receive reward or honour a particular person. A hibah provider must be the genuine owner of the item/s intended for hibah. Hibah recipient can be anyone as long as he/she has the capability to own property (Muda, 2008).

Hibah refers to a transfer of ownership of an asset from a donor (wahib) to a recipient (mawhub lahu) without a reward (Bank Negara, 2016). In other words, hibah donor makes proposal (offer) to transfer the property to the beneficiary, and in return the beneficiary accepts the proposal, with no consideration (Mujani et al, 2011;Buang, 1993).

Utusan Online, 20 January 2014 reported that RM52 billion outstanding values of the estate owned by majority of Muslims failed to be distributed to the person entitled in the country and by referring to the Chief Marketing Officer of Amanah Raya Berhad. In 2011, RM42 billions of assets were frozen due to the failure to trace the legal beneficiaries (Shafie et. al, 2014). Therefore, it is crucial for Muslims to manage their inheritance property using a more effective and efficient approach.

Currently, the distribution of wealth particularly in regards to inheritance property among Muslims is managed through the law of succession ( fara $^{\prime} i d$ ). However, the administration of property through this method in many instances were found to be less effective due to the current lifestyle people are usually occupied with day-to-day commitments and their chaotic schedules (Abdul Rashid et.al, 2013). On top of that, the process of distributing property via fara'id can be time consuming, complicated and costly (Hamid Ghul et.al, 2015). To make it worst, the process may disrupt relationships among family members due to the disputes brought forward. (Shafie et.al, 2014)

In relation to that, hibah can be viewed as an adequate solution to overcome issues concerning the use of fara'id particularly on the aspect that property may be transferred to family members with the terms of the donor's decision and choice (Abdul Rashid et.al, 2013). In addition, hibah is also a transfer of property inter vivos and takes immediate effect after the contract (Buang, 2008). Thus, the implementation of hibah will not only ensure the distribution of property to the legal beneficiaries is in accordance with donor's wishes but also to reduce the number of unsolved and complex cases in the distribution of properties through the process of fara'id (Abdul Rashid et.al, 2013).

Fara'id is known to be one complicated and less effective approach particularly on the fact that the distribution of wealth to legal beneficiaries must go through several stages involving several 
jurisdictions which may not be fully understood by the beneficiaries (Abdul Rashid et.al, 2013). On the other hand, the process of hibah is a more convenient approach as compared to fara' $i d$ because the distribution of wealth is done in accordance to donor's wishes. Under fara'id, the legal beneficiaries have the right over the deceased property and the asset must be distributed to the legal beneficiaries accordingly as stated under the Islamic Law. Therefore, each deceased's asset will be shared (or owned) by many individuals. For example, a piece of land may be owned by several owners with each one of them owning a very small size of the big land. As a result, the land or property cannot be fully developed according to one particular beneficiary's wish.

Under law of succession (fara'id), distribution of wealth must follow the portion as stated in Islamic law for example; the daughter will only get half portion of the son. In hibah, the owner of the property has the right to decide the amount and proportion of property to be distributed to the heirs according to their needs and economic condition (Abdul Rashid et al., 2013).

Under fara'id law, the property will be distributed to the legal beneficiaries only when the person is passed away. Different from fara'id, in hibah the property can be distributed to heirs while the donor is still alive. But if the donor worried about being neglected after all property being distributed to the heirs, the donor can choose to use hibah amanah, where the property will only be transferred after the death of the donor (Yaacob, 2016).

It can be seen that hibah have advantage over fara'id, however, the current situation in Malaysia, there is no specific hibah law enacted which means that the State Legislature and Parliament has never approved the special statue of hibah for muslims to be implemented in Syariah Courts. The current status of Hibah cases in the Syariah Courts in Malaysia usually involves the verification of hibah, dispute on the extent or rate of hibah and withdrawal of hibah (Mohd Yusof and Ahmad, 2013).

\subsection{Acceptance of beneficiaries on hibah}

Hibah is a practice that is favourable (sunat) in Islam especially to the immediate family. This practice based on the al-Quran, al-Sunnah and consensus. To form a hibah contract, the following conditions must be fulfilled. Among the condition are must have a hibah provider, hibah recipient, goods or property for hibah and lastly ijab (contract) and qabul (grant). When a completed hibah contract meets the terms and condition, and there has been a surrender and acceptance of goods, then the property rightfully belongs to the hibah recipient even without repayment.

According to the Hanafi sect, it is ' makruh' to withdraw hibah that has been given away. However, in the opinion of Syafie, Hambali and Maliki sects, when the hibah accompanied with the delivery and acceptance of goods then the hibah cannot be withdrawn unless the hibah is made by immediate family (eg: father, mother, grandfather, grandmother) to the children for as long as the property is not related to other people. Furthermore, based on the Prophet's saying meaning:

"One who gets back his give is like a dog which vomits and then swallows that vomit."

(By Al-Bukhari and Muslim)

Hibah cases in the Syariah Court in Malaysia, usually involves the verification of hibah, dispute on the extent or rate of hibah and the withdrawal or revocation of hibah. In the case of Eshah binti Abdullah and five others vs Che Aminah binti Abdul Razak and two others (2004) XVIII (I) JH 47 where the arising issue was whether or not the acceptance had been clearly stipulated after giving away or sufficient by other evidences to prove that was an acceptance. In this case, the

[Type here] 
donor had decease and there was no withdrawal of hibah. The building in dispute still bore the name of the deceased although the gift had been witnessed by others. The Terengganu Syariah Appeal Court accepted the appeal made by the petitioners based on the accepted qarinah (evidence) from the receiver, where all the three hibah receivers declared that they have been receiving the rental/lease (tenancy) of the disputed building since the deceased was still alive.

According to Mujani et al., (2011), in the case of Eshah Abdul Rahman vs Azuhar vs Ismail (2004), the plaintiff had his piece of land transferred to his adopted son (defendant). After filed up form 14A of the National Land Code affecting the transfer, the plaintiff changed his mind demanding the land to be returned. By then, the defendant had developed the land and had constructed several buildings thereon. The issue was whether the transfer here in constituted a hibah and if so whether the plaintiff could demand from the defendant for its return. It was held that the transfer here represented a duly constituted hibah given that the plaintiff and defendant had complied with all conditions of hibah. In regards to the issue of revocation of the said hibah, the court opined that when a value which is inseparable from the subject matter of hibah was added there to as for instance when a building was constructed by the beneficiary on the hibah land, the donor could no longer retract the gift and demand for its returns.

One of the major issues highlighted on hibah in this paper is the dissatisfaction of the beneficiary on the distribution of properties. Based on the above cases and many others, hibah can be challenged in a Syariah Court both verbally or documented by an individual or a lawyer. However, it can only be questioned in terms of legality in accordance with Islamic law or if there is any beneficiary who disagrees with the content of the hibah after the demise of the donor (Mohd Yusof and Ahmad, 2013). For that matter, many cases on hibah in Malaysia generally involves proposal to revoke a gift (hibah) earlier given to someone and questioning the validity of a gift awarded to the third party after the demise of the donor (Oseni, 2012).

The increase dispute cases among family members due to the practice of hibah may lead to crime. Increase of crime will have great impact on the quality of life of the people. It is important to take actions to help in reducing the cases due to hibah. Effort to decrease the dispute will assist the government to achieve its National Key Result Area in reducing crime.

\section{OBJECTIVE OF STUDY}

The objective of this study is to identify the acceptance of hibah by beneficiaries based on the cases registered at Melaka Syariah Court and Hibah Trust product applied with Amanah Raya Berhad Melaka.

\section{METHODOLOGY}

This study is conducted based on the data collected from Melaka Syariah Court and Amanah Raya Berhad Melaka. Interview instrument is selected for data collection. Discussion among the research member on location of interview, how the interaction with the subjects would take place and also arranged the setting of the session to ensure the appropriate level of quiet, privacy, and primer data exclusively will be gathered (Business Graduate School, 2010). Following an application letter for setting the appointment to both the Melaka Syariah Court and Amanah Raya Berhad Melaka, stating the purpose of the interview and our objective to collect the data on the number of hibah cases in these organisations for the intended study. 
An interview session with an officer from the Melaka Syariah Court was conducted regarding the registered hibah cases and their reasoning. The interview was carried out by having a preliminary meeting among the research member prior to the actual interview. Typically, such meetings were conducted roughly a week before the interview. This preliminary meeting is an opportunity to establish trust with the research member, review ethical considerations and complete consent forms. During this initial meeting, the research question has been reviewed and the lists of questions to be prepared for interview session. By going about it in this way it can aid in getting a richer description during the interview without asking too many questions to the interviewee.

Subsequently, the information data was also provided by the organization through email and telephone conversation to furnish research objective. The document reviews with the assistance of the interviewee, in the library of Melaka Syariah Court were also conducted to search if there are acts for hibah. On the other hand, the information and data from Amanah Raya Berhad Melaka were gathered through interviews via telephone conversation with the office, Puan Noraizah.

\section{FINDINGS}

\subsection{Melaka Syariah Court}

Based on the data collected from the Melaka Syariah Court from 2013-2015, the highest record on hibah was in 2015. The data result shows that there are an increase no of cases registered in Melaka state where 12 cases in 2013 followed by 22 cases in 2014 and 31 cases in 2015.

Figure 1: Trend of cases on Hibah in Melaka Syariah Court

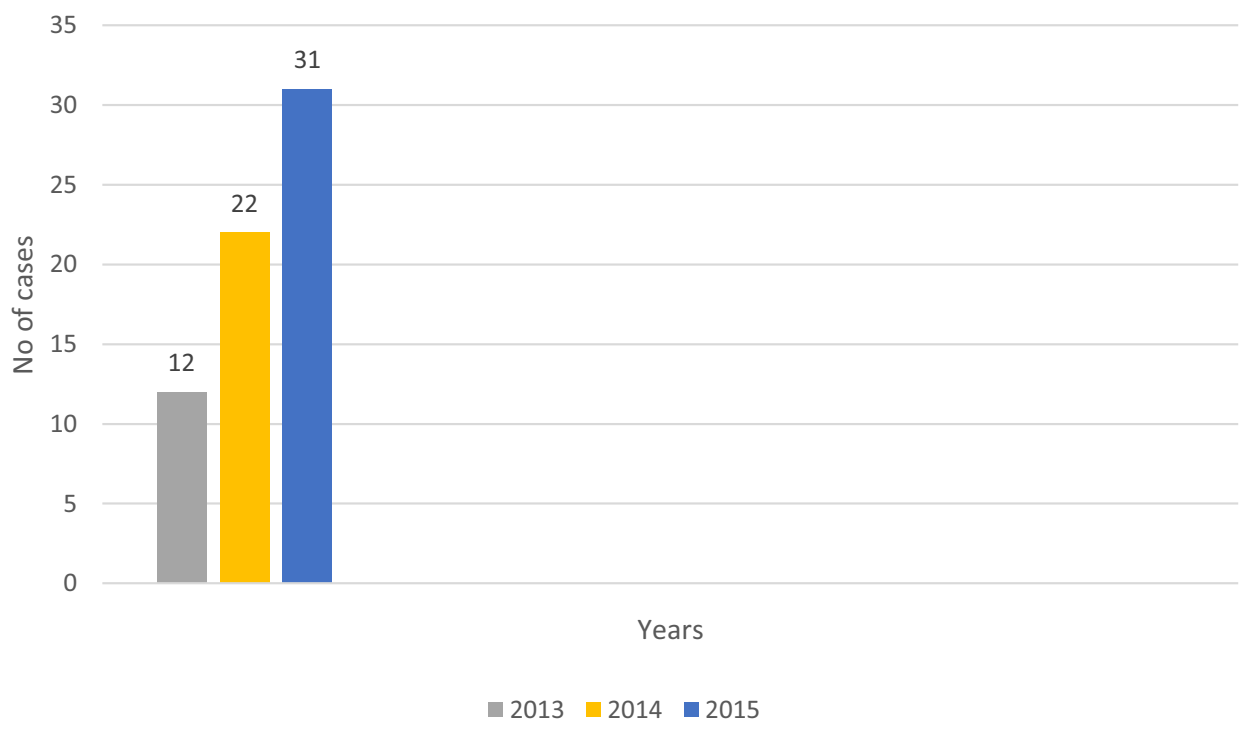


The existence of cases in Melaka Syariah Court has showed that there is still lack of acceptance or dissatisfaction by beneficiaries on Hibah which will lead them to file the case in Syariah Court. The increase number of court case shows that the giving of hibah has caused dissatisfaction among related parties especially family members who are the beneficiaries. Oseni (2012) mentioned that most cases in Syariah Court involving hibah and wassiyyah (will) - related involve family relations. This feeling of dissatisfaction may lead to dispute among related parties. Therefore, it is essential to understand the reasons to this problem. The dissatisfaction may be due to the lack of knowledge and awareness on hibah. Hibah may be done not according to any procedure.

Figure 2: No of cases registered in Melaka Syariah Court

\begin{tabular}{lc}
\hline Years & No. of cases \\
\hline 2013 & 12 \\
2014 & 22 \\
2015 & 31 \\
\hline
\end{tabular}

Based on documentation observation session at Melaka Syariah Court, it is evidenced that no such of Act or Enactment on hibah, only the Enactment on wassiyyah (will). State government of Melaka should come out with a guideline on hibah so that potential donor can follow to avoid any unforeseeable problem in the future. According to Oseni (2012), in some cases the judge may refer the parties for out-of-court settlement which should begin with a psychotherapy procedure purposefully meant to remind of their family ties and the ephemeral nature of properties and worldly life in general.

\subsection{Amanah Raya Berhad Melaka}

Amanah Raya Berhad Melaka was only started operation in May 2013. Based from the data collected from Amanah Raya Berhad Melaka there are only 1 case in 2013 and 3 cases in 2014. There is no application for Hibah Trust product in 2015. According to Puan Noraizah (Officer of Amanah Raya Berhad Melaka), client prefers to choose wassiyyah (will) as compare to Hibah product. One of the major reasons is the difficulties in preparing the documentation for hibah as compare to will and the types of asset that can be given away (Hibah). Today, various institutions and agencies are involved in documenting hibah and there are also various hibah methods have emerged (Ahmad Yusof and Ahmad, 2013).

\section{Figure 3: Number of registered Hibah Trust}

\begin{tabular}{cc}
\hline Years & Hibah Trust \\
\hline 2013 & 1 \\
2014 & 3 \\
2015 & 0 \\
\hline
\end{tabular}

Findings from these two organisations is consistent with Mohd Yusof and Ahmad (2013), where hibah are considered as new product and are recently introduced in Melaka (2013) upon realizing that it is a best method to reduce difficulties as well as to create awareness in property distribution among the Muslims in Melaka compare with will and inheritance. 


\section{LIMITATION}

The present study has several limitations that may potentially influence the interpretation of the results. The data for this study were based on the hibah cases registered for the Melaka State only. This is because the Syariah Court is governing by the State Government and there is no standard Hibah Act/Enactment yet to be established by the Malaysian Government. Each state has their owned way of handling the matters regarding hibah. Thus, it is highly suggested that the further study focused on the implementation of hibah throughout Malaysia and from there we can make comparison regarding the implementation of hibah for each state in Malaysia.

\section{CONCLUSION AND RECOMMENDATIONS}

The proper disseminations of information and knowledge on hibah can allow Muslims in Malaysia to better understand their rights when facing a dispute. By having proper understanding on this matter, parties involve may avoid further dispute. This study revealed an increasing number of registered cases on hibah dispute in Melaka Syariah Court Melaka. The growing dispute cases among family members in lieu of the poor understanding and awareness on the practice of hibah have led to a substantial number of crime cases. This may eventually have an impact on the quality of life and their harmony. It is important to take actions to help in reducing the cases due to hibah. Effort to decrease the dispute will assist the government to achieve its National Key Result Area in reducing crime. Each state needs to establish a standard Muslim Hibah Act/Enactment as reference when matters about hibah arise. It will become a guideline for the Syariah Court to decide on the validity of a hibah. Besides that, the Fatwa Committee should issue a clear and strict fatwa regarding hibah that suits the current needs and parallel with the Islamic Law requirements. Furthermore, centralised monitoring and supervision should be implemented to any agencies that manage Muslim asset especially regarding the distribution of wealth through hibah. Therefore, further study should focus on determining the reasons behind these hibah cases particularly on the aspects of dissatisfactions among legal beneficiaries or heirs in the wealth distribution held through hibah. Subsequently, the focal point here is to develop a model or a guideline which can be applied in order to reduce dissatisfactions among legal beneficiaries when distributing wealth via hibah. 


\section{REFERENCES:}

Abdul Rashid, R., Hassan, S.A. \&Yaakub, N.I., (2013).A Need For Legal Framework of Gift Inter Vivos (Hibah) In Malaysian Estate Planning. International Journal of Business, Economics and Law, Vol 2. Issue 3 (June) ISSN 2289-1552

Bank Negara, (2016). Hibah. Guideline issued as reference on the Syariah rulings applicable to hibah.

Buang, A.H., (2008).Appreciation of Syari'ah Principles in Property Management in Comtemporary Malaysian Society. Shariah Journal, Vol16, Special Edition 555-566

Buang, S. (1993) Historic Judgement on article 121 of the federal constitution, Malaysian Law News.

Hamid Ghul, Z., Yahya, M.H. \&Abdullah, A., (2015).Wasiyyah (Islamic Will) Adoption and the Barriers in Islamic Inheritance Distribution among Malaysian Muslims, International Journal of Humanities Social Sciences and Education, Vol. 2, Iss 1 pp. 1-11

Kamariah, M., (2004). Halsbury's laws of Malaysia. Malayan Law Journal, 23: 1-253.

Mohammad, M.T.S., (2015). Theoretical and trustees' perspectives on the establishment of an Islamic social (Waqf) bank, Humanomics, Vol. 31 Iss 1 pp. $37-73$

Mohd Yusof, Y. \&Ahmad, A., (2013).Hibah As An Alternative Mechanism in Muslims Assets Management: A Study in Melaka Tengah. South East Asia Journal of Contemporary Business, Economics and Law. Vol.3. Issue 3 (December) ISSN 2289-1560

Muda, M.Z., (2008), Instruments of Hibah and Wills: Analysis of the regulations and applications in Malaysia. Paper presented at the Hibah and Faraid National Convention 2008, Kuala Lumpur.

Mujani, W.K., Wan Hussain,W.M.H., Yaakub, N.I. \&Abdul Rashid, R., (2011).The concept of Law of Gift Inter Vivo Under Islamic Law and the Contracts Act, 1950. International Business Management 5(6): 319-325, ISSN: 1993-5250.

Oseni, U.A., (2012).Sharī'ah Court-annexed ADR: The Need for Effective Dispute Management in Waqf, Hibah and Wasiyyah Cases in Malaysia. In: 14th Annual Conference of the Shari'‘ah Legal Officers of Malaysia, 19th - 21st November 2012, One Lelang Hotel, Langkawi, Kedah. (Unpublished)

Sabirin, A., (2014), Umat Islam rugi berbilion ringgit kerana harta pusaka.Utusan online, 20 January 2014

Shafie, F., Wan Yusoff, W.Z. \&Dawilah Al-Edrus, S.M., (2014).Islamic Real Estate Management: Review on Issues and Challenges in Managing Inheritance Property in Malaysia. International Real Estate Symposium 7th IRERS Kuala Lumpur

The Administration of Islamic Law (Federal Territories) Act 1993 (Act 505) Part IV Sec. 46 (1) (2) (b) (vi) - Syariah High Court's Jurisdiction.

[Type here] 
Yaacob, O., (2006). Pembentukan Trust Hibah Sebagai Alternative Perancangan Harta. In Siti Mashitoh Mahamood. Harta Amanah Orang Islam di Malaysia Perspektif Undang-undang dan Pentadbiran. 174-175. Kuala Lumpur: Penerbit Universiti Malaya.

http://www.esyariah.gov.my/JurnalHukumSearch/htdocs/jurnalhukumsearch/JurnalHukumSearc hDetailsPageBM.jsp?DetailsID=612,

http://www.trinitydc.edu/sps/files/2010/09/APA-6-BGS-Qualitative-Research-Paper-August20142.pdf 